\title{
POUCHITIS: EXTRACOLONIC MANIFESTATION OF ULCERATIVE COLITIS?
}

\author{
William Gemio Jacobsen Teixeira, José Hyppólito da Silva, Magaly Gemio Teixeira, \\ Maristela Almeida, João Elias Calache and Angelita Habr-Gama
}

TEIXEIRA, W. G. J. et al. - Pouchitis: Extracolonic manifestation of ulcerative colitis? Rev. Hosp. Clín. Fac. Med. S. Paulo 54 (5):155-158, 1999.

SUMMARY: Pouchitis is the most frequent complication of ileal pouch-anal anastomosis for treatment of ulcerative colitis. There are several possible explanations. Among them, we focus on the one that considers pouchitis as an extracolonic manifestation of ulcerative colitis. The aim of this study was to investigate the association between pouchitis and extra-intestinal manifestations (EIM), which are frequent in these patients. Sixty patients underwent restorative proctocolectomy with an ileal J pouch (IPAA) from September 1984 to December 1998. Pouchitis was defined by clinical, endoscopic, and histologic criteria. The following extra-intestinal manifestations were studied: articular, cutaneous, hepatobiliary, ocular, genitourinary, and growth failure. Thirteen patients, of which 10 were female (76.9\%), developed one or more episodes of pouchitis. Twelve patients of this group (92.3\%) presented some kind of extra-intestinal manifestation, 4 pre-operatively (exclusively), 2 post-operatively (exclusively), and 6 both pre- and postoperatively (1.7 per patient). Twenty patients $(42.7 \%)$ of the 47 without pouchitis did not present extra-intestinal manifestations; $10 / 35$ (28.5\%) of females had pouchitis, compared to 3/35 (12.0\%) of men. Pouchitis was more frequent among females, though not statistically significant. EIM increases the risk of pouchitis. Pouchitis is related to EIM in $92.3 \%$ of cases, corroborating the hypothesis that it could be an extracolonic manifestation of ulcerative colitis.

DESCRIPTORS: Ulcerative colitis. Ileal-pouch anastomosis. Extraintestinal manifestations. Pouchitis surgery.

Abdominal colectomy together with ileal pouch-anal anastomosis (IPAA) has become the standard surgical therapy for uncontrolled ulcerative colitis (UC). Pouchitis is the most frequent late complication of IPAA ${ }^{17}$, 19,26 . The incidence increases over time. The majority of cases are easily resolved by clinical means, but some eventually can be of such morbidity that resection of the ileal reservoir is required. There are several possible explanations for the development of pouchitis. We focus in the one that considers it as an extracolonic manifestation of ulcerative colitis. The objective of this study was to investigate the association between pouchitis and extra-intestinal manifestations of ulcerative colitis.

\section{METHODS}

Sixty patients underwent IPAA between September 1984 and December 1998. Thirteen $(21.7 \%)$ developed pouchitis. The mean age of operated patients that developed pouchitis was 25.5 years and 26.6 for the group without pouchitis.

The average time between first symptoms and operation was 6.3 years. Mean follow-up was 10.9 years.

Patients were questioned about the following aspects concerning articular complications: pain, joints affected,

From the Department of Coloproctology, University of São Paulo School of Medicine, São Paulo - Brazil. migratory character, presence of edema, redness and deformity, and association with intestinal symptoms. Only patients with negative tests for rheumatoid arthritis were included.

The hepatobiliary manifestations were studied through laboratory tests to evaluate hepatic function and abdominal ultrasound. Hepatic biopsy was obtained during operation.

Genitourinary complications were studied by laboratory tests and ultrasound.

All patients were examined by an ophthalmologist.

Cutaneous lesions were studied and, if necessary, biopsy was obtained for definitive diagnosis.

Patients presenting growth failure were studied to exclude other causes. 
The criteria adopted for characterisation of pouchitis were clinical, endoscopic, and histologic. The clinical criteria included increased number of stools per day above the expected number to each patient, bleeding, urgency, and fever. The endoscopic criteria were edema, granularity, friability, and loss of vascular pattern, mucosal exudate and ulceration. The histological criteria were polymorphonuclear leukocytes infiltration associated or not with crypt abscesses and ulceration.

\section{Statistical analysis}

Presence or not of pouchitis and association with gender and association of IPAA with and without pouchitis with EIM were compared using Fisher's Exact test.

\section{RESULTS}

Pouchitis was about three times more frequent in females, though without statistical significance (Table 1).

Table 1 - Gender and distribution of patients with and without pouchitis.

\begin{tabular}{lcr}
\hline & \multicolumn{3}{c}{ Gender } & \\
\hline Pouchitis & females & males \\
\hline Without & $25(53.2 \%)$ & $22(46.8 \%)$ \\
\hline With & $10(76.9 \%)$ & $3(23.1 \%)$ \\
\hline
\end{tabular}

Twelve of 13 patients $(92.3 \%)$ that developed one or multiple pouchitis episodes presented at least one EIM. Extra-intestinal manifestations disappeared after IPAA in four patients (30.8\%), two (15.4\%) developed EIM after IPAA, and six (46.1\%) presented EIM before and after surgical treatment.

The following types of EIM were diagnosed: arthritis (11 patients), osteoporosis (1), sclerosing cholangitis (1), fatty liver (1), cholelithiasis (1), sexual disturbances (1), erythema nodosum (2), pyoderma gangrenosum (2), conjunctivitis (1), and growth failure (1).

The distribution of patients with pouchitis and EIM is shown in table 2. The average number of EIM was 1.7 per patient.

Forty-seven patients did not develop pouchitis. Twenty had not presented any type of EIM (42.6\%), 14 $(29.8 \%)$ presented EIM that resolved after IPAA, two $(4.3 \%)$ presented EIM only after IPAA, and $11(23.4 \%)$ had EIM in the pre- and post-operative period (Table 4).

The number of patients with or without pouchitis that did or did not present EIM during the evolution of $\mathrm{UC}$ is shown in table 3. The association of pouchitis with EIM was statistically significant.

\section{DISCUSSION}

The reservoir ileitis, a diverse entity of recurrent inflammatory bowel disease, was first described by Kock et al. ${ }^{11}$ on patients with continent ileostomy. This inflammation caused malfunction of the reservoir and was characterised by bacteriological and histological alterations inside the reservoir. The edema in the distal reservoir sometimes precludes the catheterization of the valve, causing intestinal obstruction. In that study reservoir ileitis occurred in $17 \%$ of patients. The fact that a similar situation would appear after ileal pouch-anal anastomosis was therefore expected.

It is believed that the inflammatory reservoir process occurs among $8 \%$ to $29 \%$ of patients undergoing ileal pouch-anal anastomosis 3,7,10,12,18,21,22. The frequency of this complication seems to increase with the length of follow-up ${ }^{14,29}$. Meagher et al. ${ }^{14}$ reported an incidence of $18 \%$ at the end of the first year after the operation and of $48 \%$ after 10 years. The cumulative probability of losing the reservoir after one and 10 years is respectively $2 \%$ and $9 \%$. Pouchitis normally occurs between two days and 95 months after ileostomy closure ${ }^{9,22}$. It is manifested in single or multiple episodes ${ }^{12,}{ }^{13}$. Some authors believe that it occurs only in patients with ulcerative colitis ${ }^{4,5,27}$. However, it was described in $6 \%$ to $7 \%$ of patients operated on for familial polyposis coli ${ }^{6,12}$.

Pouchitis is a troublesome chronic disease with serious implications concerning professional and social life of patients, even when there is a rapid clinical response to therapy.

Table 2 - Patients with pouchitis and type of EIM.

\begin{tabular}{lccc}
\hline EIM & pre IPAA (exclusive) & post IPAA (exclusive) & pre and post IPAA \\
\hline Articular & 4 & 2 & 5 \\
Hepatobiliary & 0 & 0 & 2 \\
Urologic & 0 & 1 & 0 \\
Cutaneous & 2 & 0 & 1 \\
Growth Failure & 0 & 0 & 1 \\
\hline
\end{tabular}

Table 3 - EIM and presence or absence of pouchitis.

\begin{tabular}{lccc}
\hline Pouchitis & With EIM & Without EIM & Total \\
\hline With & 12 & 1 & 13 \\
\hline Without & 27 & 20 & 47 \\
\hline Total & 39 & 21 & 60 \\
\hline
\end{tabular}

Fisher's Exact test: $\mathrm{p}=0.023$. 
Clinical diagnosis is based on the presence of abdominal pain, liquid diarrhoea sometimes with blood, urgency, incontinence, fever, and malaise.

The endoscopic findings do not always have direct relationship to symptoms. O'Connell et al. ${ }^{19}$ have not found typical morphological abnormalities in patients with recurring inflammation of the reservoir. Tytgat ${ }^{28}$ suggested that mild inflammation is characterised by edema, friability, mucosal erythema, and mucopurulent exudate. The moderate form shows superficial ulceration. Severe form shows diffuse erythema, intense exudate and extensive superficial necrosis. Many authors prefer clinical diagnosis to characterize pouchitis since the histological parameters are debatable ${ }^{9}$. It seems that chronic inflammatory lesions are universal $^{15,19,27}$, and villous atrophy is intensity variable ${ }^{27}$. However, the chronic inflammation is not related to the number of bowel motions ${ }^{19}$. Some degree of inflammation is found in $38 \%$ to $64 \%$ of the reservoirs ${ }^{17,24,27}$, but crypt abscesses and ulceration occur only on symptomatic pouchitis ${ }^{27}$. The endoscopic characteristics resemble ulcerative colitis.

The etiology is still unknown. Some authors have correlated the histopathology of the terminal ileum and the extension, but not the intensity of colonic disease with reservoir ileitis $^{25}$. Another hypothesis for the etiological factor suggest stasis, motivated by poor contractile reservoir, flow obstruction by stenosis, or functional obstruction due to long reservoir $^{8}$. It is difficult to differentiate reservoir inflammation and dysfunction. Several studies have demonstrated that although stasis does occur, there is no correlation between the type of reservoir used, complacency, maximal tolerated volume, or reservoir emptying, as well as reservoir inflammation and villous atrophy ${ }^{17,18}$.

Sometimes, stenosis can impede reservoir emptying and can favour recurrent inflammatory episodes. Pouchitis incidence decreases after stenosis treatment ${ }^{6}$.

The resolution of pouchitis with metronidazole supports the hypothesis that bacteria are an etiological factor. The study of pouch bacterial flora has shown an increase in the total number of bacteria and in the ratio between anaerobic and aerobic bacteria 16,23,24. These alterations are not strictly related to clinical symptoms. The mucosal epithelial cells of the ileum are protected from trauma, action of antigen and toxins, and the invasion of enteric bacteria by a layer of mucus glycoproteins. The mucus secreted by goblet cells consists of a glycoprotein that contains $85 \%$ carbohydrates. This production is independent of oral intake and thereafter is available in roughly equivalent amounts. Mucus is used by intestinal bacteria as a source of energy. In a normal pouch, there is a balance between glycoprotein secretion by goblet cells and the degradation by intestinal flora ${ }^{23}$. In the case of pouchitis, Ruseler van Embden et al. ${ }^{23}$ found that the flora composition varies with the ratio of anaerobes to aerobes, changing from 143 to 2 . The bacterial antigens could start a local inflammatory reaction.

Another possible etiological factor for pouchitis is ischemia. Ischemia can occur when mesenteric vessels are cut in order to reduce tension in the ileal pouch-anal anastomosis. Difficulty in emptying the pouch associated or not with stenosis could also cause increased pressure on the reservoir determining mucosal ischemia.

Development of EIM similar to those observed in inflammatory intestinal disease is a troublesome complication. Four percent of patients undergoing ileal pouch-anal anastomosis having no EIM before operation have developed them after operation ${ }^{12}$. Pouchitis has occurred in $39 \%$ of patients with EIM before operation and in $26 \%$ of patients without them ${ }^{12}$. On our study, pouchitis occurred in $28.6 \%$ and $12 \%$ of patients in those situations respectively. Some type of EIM was diagnosed on $92.3 \%$ of patients with pouchitis compared to $42.6 \%$ in the group without.

We report a high number of articular complications, probably because our study is prospective; $25 \%$ of the patients began to complain of articular problems after the operation. Articular manifestations have been described, but are not always associated with pouchitis, since most of the studies were not prospective. Association of sclerosing cholangitis with IPAA has been demonstrated ${ }^{20}$.

Some findings support the theory that pouchitis could be an extracolonic manifestation of ulcerative colitis on ileal mucosa that is slowly altered, acquiring a similar aspect to colonic mucosa ${ }^{13}$. The gradual development of colonic metaplasia on ileal reservoirs added to alterations on sialomucin encountered in small bowel to sulfomucin encountered in colon has already been described ${ }^{15,27}$. These alterations could be more intense in patients that developed reservoir inflammation. It is possible that patients with persistent pouchitis would be more prone to dysplasia, and for this reason, they should frequently undergo reservoir examination ${ }^{13}$.

Pouchitis has been considered as a form of undetermined colitis or Crohn's disease ${ }^{12}$. This theory is not accepted by all, since many series have not shown any case of Crohn's disease, even with long follow-up ${ }^{13}$.

It is possible that the same etiological factor that induces EIM is responsible for pouchitis.

\section{CONCLUSIONS}

Pouchitis was more frequent among females, though not statistically significant.

EIM increases the risk of pouchitis.

Pouchitis is related to EIM in $92.3 \%$ of cases, corroborating the hypothesis that it could be an extracolonic manifestation of ulcerative colitis. 
TEIXEIRA, W. G. J. e col. - Pouchitis: Mainfestação extracolônica da retocolite ulcerativa? Rev. Hosp. Clín. Fac. Med. S. Paulo 54 (5): 155-158, 1999.

A bolsite é a complicação mais freqüente da anastomose íleo-anal com reservatório realizada para o tratamento da retocolite ulcerativa. Há várias hipóteses para explicá-la. Entre elas, focalizamos a que a considera como manifestação extracolônica da retocolite ulcerativa. O propósito deste estudo foi o de investigar a associação entre bolsite e manifestações extra-intestinais que são freqüientes nestes doentes. Sessenta doentes foram submetidos a colectomia com anastomose íleo-anal e reservatório em $\mathbf{J}$ de setembro/84 a dezembro/98. A bolsite foi definida por critérios clínicos, endoscópicos e histológicos. Foram estudadas as seguintes manifestações extra-intestinais: articulares, cutâneas, hepatobiliares, oculares, genito-urinárias e retardo de crescimento. Treze doentes dos quais $\operatorname{dez}(76,9 \%)$ eram mulheres desenvolveram um ou mais episódios de bolsite. Doze doentes deste grupo $(92,3 \%)$ apresentaram manifestação extra-intestinal, sendo quatro exclusivamente no período pré-operatório, dois exclusivamente no pós e seis tanto pré como pós operação (1,7 manifestação/doente).
Vinte doentes $(42,7 \%)$ dos 47 sem bolsite não apresentaram nenhuma manifestação extra-intestinal. No grupo sem bolsite, 25 eram mulheres $(53,2 \%)$. A bolsite foi mais freqüente em mulheres, embora não estatisticamente significante. A presença de manifestação extra-intestinal aumenta o risco de bolsite. A bolsite está relacionada a manifestação extra-intestinal em 92,3\% dos casos, corroborando a hipótese de que seria uma manifestação extracolônica da retocolite ulcerativa.

DESCRITORES: Retocolite ulcerativa. Anastomose íleo-anal. Manifestações extra-intestinais.

\section{REFERENCES}

1. ANDREYEV HJN et al. - Joint Symptoms after restorative proctocolectomy in ulcerative colitis and familial polyposis coli. J Clin Gastroenterol 1996; 23: 35-39.

2. AXON JMC, HAWLEY PER \& HUSKINSSON EC - Ileal pouch arthritis. Br J Rheumatol 1993; 32: 586-588.

3. BEART RW - Proctocolectomy and ileoanal anastomosis. World J Surg 1988; 12: 160- 163.

4. BECKER JM - Ileal pouch-anal anastomosis: Current status and controversies. Surgery 1993; 113: 599-602.

5. BECKER JM \& RAYMOND JL - Ileal pouch-anal anastomosis: a single surgeon's experience with 100 consecutive cases. Ann Surg 1986; 204: 375-383.

6. DOZOIS RR et al. - Ileal pouch-anal anastomosis: comparison of results in familial adenomatous polyposis and chronic ulcerative colitis. Ann Surg 1989; 210: 268- 273.

7. FLESHMAN JW et al. - The ileal reservoir and ileoanal anastomosis procedure: factors affecting technical and functional outcome. Dis Colon Rectum 1988; 31: 10-16.

8. FONKALSRUD EW \& PHILLIPS JD - Reconstruction of malfunctioning ileoanal pouch procedures as an alternative to permanent ileostomy. Am J Surg 1990; 160: 245-251.

9. FOZARD BJ \& PEMBERTON JH - Results of pouch surgery after ileo-anal anastomosis: the implications of pouchitis. World J Surg 1992; 16: 880- 884.

10. HABR-GAMA A et al. Restorative proctocolectomy with ileo-anal J pouch anastomosis for treatment of ulcerative colitis. ABCD Arq Bras Cir Dig, São Paulo 1992; 7: 72-78.

11. KOCK NG et al. - Ileostomy. Curr Probl Surg 1977; 14: 18-49.

12. LOHMULLER JL et al. - Pouchitis and extraintestinal manifestations of inflammatory bowel disease after ileal pouch-anal anastomosis. Ann Surg 1990; 211: 622-629.

13. LUUKKONEN $P$ et al. - Pouchitis - recurrence of the inflammatory bowel disease? Gut 1994; 35: 243-246.

14. MEAGHER AP et al. - $\mathrm{J}$ ileal pouch-anal anastomosis for chronic ulcerative colitis complications and long term outcome of 1310 patients. Br J Surg 1998; 85: 800-803.

15. MOSKOWITZ RL, SHEPERD NA \& NICHOLLS RJ - An assessment of inflammation in the reservoir after restorative proctocolectomy with ileoanal ileal reservoir. Int J Color Dis 1986; 1: 167-174.

16. NASMYTH DG et al. - Ileal ecology after pouch-anal anastomosis or ileostomy: a study of mucosal morphology, fecal bacteriology, fecal volatile fatty acids and their interrelationship. Gastroenterology 1989; 96: 817-824.

17. NASMYTH DG et al. - Factors influencing bowel function after ileal pouch-anal anastomosis. Br J Surg 1986; 73: 469-473.

18. NICHOLLS RJ, MOSKOWITZ RI \& SHEPERD NA - Restorative proctocolectomy with ileal reservoir. Br J Surg 1985; 72 (suppl): S76.

19. O'CONNELL PR et al. - Enteric bacteriology, absorption, morphology and emptying after ileal pouch-anal anastomosis. Br J Surg 1986; 73: 909-914.

20. PENNA C et al. - Pouchitis after ileal pouch-anal anastomosis for ulcerative colitis occurs with increased frequency in patients with associated primary sclerosing cholangitis. Gut 1996; 38: 234-239.

21. PESCATORI M, MATTANA C \& CASTAGNETO $M$ - Clinical and functional results after restorative proctocolectomy. Br J Surg 1988; 75: 321-324.

22. RAUH SM et al. - Pouchitis - Is it a wastebasket diagnosis? Dis Colon Rectum 1991; 34: 685-689.

23. RUSELER-VAN EMBDEN JGH, SCHOUTEN WR \& VAN LIESHOUT LMC - Pouchitis: result of microbial imbalance? Gut 1994; 35: 658-664,

24. SANTAVIRTA J et al. - Mucosal morphology and faecal bacteriology after ileo-anal anastomosis. Int J Color Dis 1991; 6: 38-41,

25. SCHMIDT CM et al. - Preoperative terminal ileal and colonic resection histopathology predicts risk of pouchitis in patients after ileoanal pull-through procedure. Ann Surg 1998; 227: 654-662.

26. SCHOETZ DJ, COLLER JÁ \& VEIDENHEIMER MC - Ileoanal reservoir for ulcerative colitis and familial polyposis. Arch Surg 1986; 121: 404-409.

27. SHEPHERD NA et al. - Restorative proctocolectomy with ileal reservoir: pathological and histochemical study of mucosal biopsy specimens. J Clin Pathol 1987; 40: 601-607.

28. TYTGAT GNJ - The role of endoscopy in pouch monitoring and pouchitis: pouchitis workshop. Int J Color Dis 1989; 4: 205-229.

29. WEXNER SD et al. - The ileoanal reservoir. Am J Surg 1990; 159:178185. 